\title{
RED: THE COLOUR AND THE WORD
}

\section{$\underline{\text { Virve Sarapik }}$}

This paper could be named an echo of an echo. Its primary impetus was given by Brent Berlin and Paul Kay"s Basic Color Terms: Their Universality and Evolution (Berlin, Kay 1969), a work that today has become a classic that can hardly be ignored when speaking about the relations of colours and language.

The following years saw the publication in Estonia of a number of articles dealing with the terms, psychology, and symbolism of colours (Allik 1982, Eelsalu, Stöör 1984, Parmasto 1982, Randlane 1975, Roll 1985, Rätsep 1985, M. and T. Sarv 1979, 1980, Viires 1983, Õim 1983). The weightiest of all these treatments is, no doubt, A. Viires's Eestlaste värvimaailm ('The Estonian's World of Colours') - not so much an exhaustive treatise, but a good example of a perfectly posed question. The Finnish analogue was Mauno Koski's comprehensive monograph Värien nimitykset suomessa ja lähisukukielissä (Koski 1983). Both take Berlin and Kay's theory as their point of departure, and in both cases it is confirmed, with some concession, in the Balto-Finnic languages.

Berlin and Kay's main postulations need not be introduced here in detail, as there are enough reviews of them in Estonia (Allik 1982, Parmasto 1982, Viires 1983). Some of the specifications of their theory will be discussed below. To make it very brief, Berlin and Kay's main conclusion was that the basic colour terms are universals, i.e. their meanings in different languages coincide and that they appear in languages in a certain order.

The authors who have relied on Berlin and Kay's hypothesis (e.g. Boynton, Olson 1987; Bornstein 1973; Witkowski, Brown 1978; Hardin 1988; Kay, McDaniel 1978; Kuschel, Monberg 1974; Turton 1980, etc.) try to demonstrate its validity and elaborate the theory without changing its essence. One of the most important articles here is obviously Paul Kay's and Chad K. McDaniel's The Linguistic Significance of the Meanings of Basic Color Terms (Kay, McDaniels 1978).

\section{The Colour and the Word}

The theory of colours has always been and will be a strongly interdisciplinary study. The so-called classical colour theory would include optics and the divisions of chemistry dealing with exact measurements of light (or rather its wave length) and pigmentary colours, their origin, combinations (both additive and subtractive) and interactions. In addition, there is the study of colour perception as a part of theory of human vision. So one may say that the colour theory does not exist as an autonomous field of study. In a broader view colours are also treated in the theories of different arts, psychology, linguistics (colour names), etc. In fact, it is the names for colours that add a new plane to the colours and colour perception, giving us a more complicated connexion:

$$
\text { colour } \mathrm{P}_{1} \text { - perception - designation/word - association - colour } \mathrm{P}_{2}
$$

The primary colour $\mathrm{P}_{1}$ is what we see and encode, for example, into a word, a colour name. The encoding can also be numerical, e.g. the standard or catalogue number of a colour, etc. Uttering, 
hearing or reading a word denoting a colour, i.e. in a process of communication, the corresponding association $\mathrm{P}_{2}$ arises, which not necessarily corresponds with the original colour. This could be explained with the following reasoning.

1.1. In comparison with the other visually perceived quality, form, colour is characterized by a considerably weaker capacity of abstraction. A red ball is better characterized by its roundness or the geometrical figure - the sphere - rather than its red colour. Of course, one can also find examples to the contrary. In the first place one thinks of an orange, which really seems to be best characterized by its colour. At the same time, the orange colour of an orange is associated with its shiny and uneven peel; the same colour with a different surface texture does not necessarily remind us of an orange.

Psychology uses the so-called colour and form tests to find out the relationship between form and colour. People of different ages and nationalities are asked to group a number of objects according to a characteristic that they find suitable for themselves (studies of colour and form have been done by R. Scholl, D. Katz, H. Rorschach). For example, there are yellow, blue and red cubes, cones and spheres that the informant must group either according to the colour or according to the form. Or a child is shown a blue square and a red circle and asked whether a red square resembles the square or the circle. Children under six tend to group objects according to the colour, while those over six (i.e. schoolchildren) group them according to the form (Arnheim 1974:335 Hdb der Psychologie 1959:59). There are also some ethnic differences: people from the southern countries are more inclined to group things according to the colour, while northerners tend to group them according to the form. According to H. Rorschach and E. G. Schachtel, the preference of form or colour also depends on the person's mood; extroverts are said to prefer colour and introverts form (Arnheim 1974: 336).

However, these tests make allowances to the colour, or rather, the colours of the figures have been made more similar to each other with the help of a similar surface texture. If, for example, the items to be grouped were a red and a blue lamp, and a red and a blue armchair, or even armchairs and spheres, even a child would hardly group them according to the colour. So it seems that in the human mind form is more abstracted than colour or, rather, it functions more as a categorizing quality. Hence the evident conclusion that colour is much more related to an object than form. I am inclined to support the view (see Norman, Scott 1952) that colour is almost invariably associated with a certain object or phenomenon. Even when speaking about colored light we cannot say that it is the very colour in its pure essence, but rather that it is light of certain colour. The recent researches on perception indicate that colour and form are perceived through different channels of the brain (Livingstone 1988, Boynton 1975, R. L. De Valois, K. K. De Valois 1975).

1.2. The colour memory is extremely short. It seems that to preserve the colour in memory for a longer period, a human being uses verbal encoding, i.e. the medium of a word. So colour is an important means for distinguishing objects, but not for their recollection. Therefore, although a human being can differentiate between 100,000 hues, in dangerous situations (e.g. in traffic) only seven colours can be used in the function of a signal (Boynton 1975, Boynton et al., 1989).

1.3. For exact definition of a certain colour at least three characteristics are necessary: hue, saturation or chroma (colorfulness), and lightness or value. Therefore all colour models and systems are three-dimensional, because two dimensions simply cannot comprise all different hues. The colour domain that is signified with a certain colour term, is also three-dimensional. This colour domain occupies all colours for which we can use that particular colour name. So we can speak about yellow, red, etc., colour domain. For example, we can say red brick, ochre, flag, sky, cow, flame, hair, although we perceive the colour of all these objects as quite different. And yet, all the 
colours labelled as red are more similar to each other than all the different shades of colour that we classify as brown. In other words, the colour domain embraced by the word brown is obviously larger than that of red. So the colour domains corresponding to the basic terms are of different extent and partially overlapping.

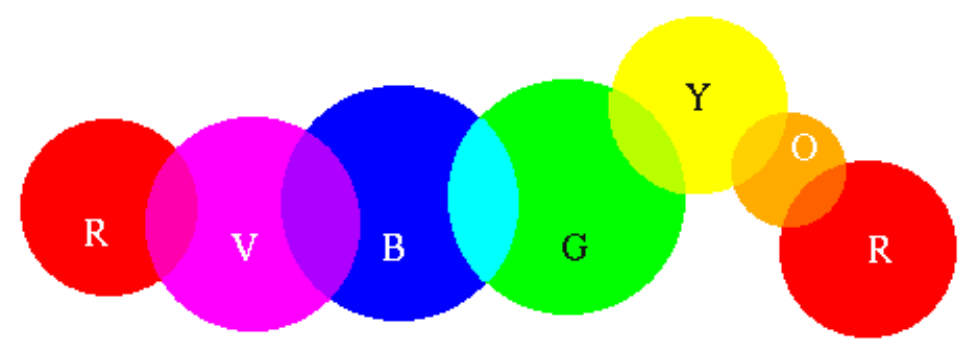

Figure 1. The relative colour domains corresponding to the basic colour terms (based on Berlin and Kay's test results (see Berlin, Kay 1969: Figure 2, 3; Appendix 1 and Koski 1983: Figure 10; Boynton, Olson 1987)

It is possible to speak about two different criteria - all conceivable colours that can be signified with the word red, and the most appropriate colour, the best example of that particular term. The latter has usually been called the focus of that colour.

Returning to the connection $\mathrm{P}_{1} \ldots \mathrm{P}_{2}$, we may say that the association created with the mention of a colour name is always more strictly demarcated and probably coincides roughly with the focus. Thus $\mathrm{P}_{2}$ is always narrower than $\mathrm{P}_{1}$, and usually located within the latter as a concentric circle.

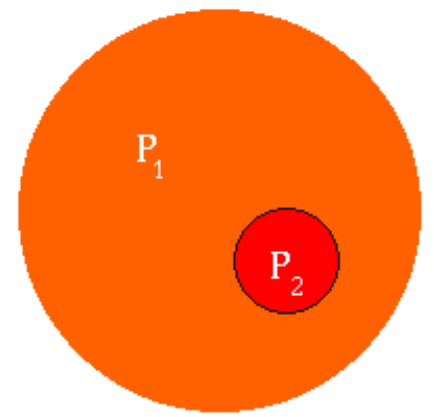

Figure 2. The relationship between the colour domain designated with a colour term and the association colour corresponding to the colour term.

Of course, this diagram applies only to the cases where the colour word is abstract, not implying the colour of any particular object or phenomenon. Hardly anybody would think of the focal red when speaking about a red cow grazing on a meadow. At the same time the association created at the mention of the word red is usually one of the most exactly determined, being mostly identified with crimson or the colour of blood. It seems, however, that the foci are not so important problem in itself. Their relations with the human colour perception are, in fact, logical enough. More interesting is the question of the difference or similarity of the limits of a colour domains in different languages. It is evident that the larger the colour space, the greater the divergence of the focal colour (e.g. which hue of green is the most typical green?). 


\section{Colour Word and Colour Perception}

2.1. Colour terms have been an enticing theme in the linguistics from handy examples up to comprehensive treatises. The reason for that is surely the, at first sight, simple system of colour vocabulary and the limited amount of words. It is a paradox that colour terms had been used as paradigmatic examples by contrasting theories. Broadly these can be divided in two trends:

(a) Cultural relativism, i.e. the theories stressing the primacy of the culture and the language for human cognition and non-linguistic behavior. The most typical one is Edward Sapir's (1921) and Benjamin Lee Whorf's (1956) theory of linguistic relativity. According to that each language is semantically arbitrary relative to every other language. So different languages categorize the colour continuum in a different way and a certain colour term in one language need not signify the same colour domain as its equivalent in another language. This would mean that the association colour evoked in different languages by the word red is different. All colour names within the semantic space of colours of that particular language have an equal status that does not depend on their different frequency of usage. The signification of a colour name, e.g. red, does not depend on some kind of quality in the surrounding world or on the visual perception of the speaker. This only depends on the position of the word within the structure of semantic space of colours of that particular language. If a language has the words for orange and yellow, it certainly reduces the sphere of denotation of red. So language is unquestionably primary to the perception of colours and affect its development.

The cultural relativist conception of colour terms, as it drifts from work to work, was formulated already by L. Bloomfield (1933:140): "Physicists view the color-spectrum as a continuous scale of light-waves of different lengths, ranging from 40 to 72 hundred-thousandths of a millimeter, but languages mark off different parts of this scale quite arbitrarily and without precise limits, in the meanings of such color-names as violet, blue, green, yellow, orange, red, and the color-names of different languages do not embrace the same gradations."

Until the publication of Berlin and Kay's Basic Color Terms such opinions were widespread. In fact, it is possible to take their hypothesis as a counterbalance to Sapir and Whorf's relativism (1969:1-2).

After the publication of Berlin and Kay's book there came numerous objections from the supporters of cultural relativity theory. However, many authors have supported the view in their occasional remarks. There is, for example, the common migratory example of the differences in the categorization of spectral colours in different languages (e.g. Tulviste 1981:330; H. Õim 1974:7879; Sahlins 1976; Eco 1976:77; 1985).

(b) Linguistic universalism, development hypotheses. The research works of this group proceed from the axiom that the basic colour terms in a language correspond to certain foci in the colour continuum, determined by our perception, therefore these are semantic universals. Since human (and not only human) perception essentially divides the spectrum in a similar manner, into similar categories, therefore these categories correspond to colour terms with similar meanings in different languages. The authors who share this opinion might be called colour universalists. They stress the universality of basic colour terms in different languages, their independence from the particular culture: the focal colour, the corresponding colour perception and term are in one-to-one correspondence. The most typical example is definitely Berlin and Kay's hypothesis of the evolution of basic colour terms (1969), according to which the development of material culture (technology) induces the transition of the language from one stage to the next, but the essence and sequence of the stages is determined by the neurophysiology of colour perception (see also Kay, McDaniel 1983). 
Broadly speaking, this is a question of the autonomy of language in relation to other aspects of culture and the so-called pan-linguistic laws that take the psycho-physiological rather than geographic or cultural determination of a language as their point of departure. In other words, while the supporters of cultural relativism stress the primacy of language to thinking, its influence on the person's world view and the mutual relations of language and other aspects of culture, universalists, on the other hand, emphasize that language is determined by common basic structures and at least the terms of the abstract categories of perception (incl. colour terms) are secondary to perception.

Between these two extremes all theories should find their place that proceed from the material available in a language (and culture in general), i.e. that use the method of deduction, while taking into consideration the existing development hypotheses. At best they also take into consideration the perception of colours. These would include Koski's (1983) and Viires's (1983) treatments.

2.2. What a human being perceives as colours are in fact light of certain wave length. The result of the visual process in the human consciousness is a coloured image of the surroundings, which in fact has no equivalent in reality - a good material for an agnostic. Hence the questions: are the coloured images of the same object seen by two persons different, i.e. do human beings perceive colours similarly? (level I - perception); do they speak about it in a similar manner? (level II concepts/language); do they understand each other adequately? (level III - association and communication).

That human beings perceive colours similarly seems to be the generally shared opinion of perception psychologists. As for the next level - the identical expression of their identical perception - the opinions are not so accordant, as we could see above. From the point of view of the "colour universalists" the communication between people speaking different languages would be easy. The focal colours resulting in the categorization of the colour continuum conform with colour names that are in one-to-one correspondence in different languages.

Since the mid-19th century two directions in the studies of colour perception have been in competition:

a) Component theories, in the first place Young-Helmholtz' principle of trichromatic colour vision that takes three primary colours (red, green, violet) as a basis;

b) Hering's opponent theory of colour vision , founded on two opposite pairs - red-green and blueyellow. Here another opposition, that of black and white, is also important, so that with some concessions we can speak of six primary colours.

By the second half of this century this antagonism seemed to have come to an end. The opinion that the retina contains three types of cones that are not sensitive to colours, but to certain wave length, is by now generally accepted. The coded visual information (changed into impulses) arising on the retina is further treated in the following perception process by four types of spectrally opponent cells. Thus we can say that colour perception is based on simultaneously three and four primary colours (Boynton 1975; R. L. De Valois, K. K. De Valois 1975; Livingstone 1988).

\section{The Basic Colour Terms}

At this point we should go back to Berlin and Kay's hypothesis. The notion basic colour term is defined by them through four characteristics. If with these four it is not quite clear whether that particular colour term is a basic one, there are four more characteristics. So the basic colour term should meet the following requirements: 
(I) It is a monolexeme; that is, its meaning is not predictable from the meaning of its parts.

(II) Its signification is not included in that of any other color term.

(III) Its application must not be restricted to a narrow class of objects.

(IV) It must be psychologically salient for informants. Indices of psychological salience include, among others, (1) a tendency to occur at the beginning of elicited list of color terms, (stability of reference across informants and across occasions of use, and (3) occurrence in the ideolects of all informants.

If these characteristics leave room for doubt, then:

(V) The doubtful form should have the same distributional potential as the previously established basic terms. For example, in English, allowing the suffix -ish, for example, reddish, whitish, and greenish are English words, but *aguaish and *chartreus (e) ish are not.

(VI) Colour terms, that are also the name of an object characteristically having that color are suspect, for example, gold, silver, and ash. This subsidiary criterion would exclude orange, in English, if it were a doubtful case on the basic criteria (i-iv).

(vii) Recent foreign loan words may be suspect.

(viii) In cases where lexemic status is difficult to assess [see criterion (i)], morphological complexity is given some weight as a secondary criterion. The English term blue-green might be eliminated by this criterion. (Berlin, Kay 1969, 5-7).

A position of a particular kind seems to have Estonian polysemantic valge ('white; light') and must ('black; dirty'). There is also a confusion with the words lilla, violett, violetne and purpur ('lilac', 'violet', 'purple'). In fact, it is not easy to determine the basic colour terms unambiguously according to the given features. For example, it seems that Estonian bee_, ('beige') would also belong to these, at least in the Estonian language it is in the same position as the other recent loans, oranž, purpur and violett ('orange', 'purple', 'violet'). Lilla ('lilac, violet') and roosa ('pink') seem to be better adapted in Estonian. M. Koski's list of the Estonian basic colour terms includes valge, must, sinine, punane, kollane, roheline, hall, pruun, roosa, lilla ('white, black, blue, red, yellow, green, grey, brown, pink, purple'), and with some doubts also oran_('orange'), while he omitted violett (violetne), purpur and beež ('violet, purple', 'purple' and 'beige', respectively) as not so indubitable examples. (NB! Berlin and Kay do not have the last mentioned colour name; Koski 1983:267). In the Finnish language he does not count pinkki and beige as basic terms; thus the list is valkoinen, musta, sininen, punainen, keltainen, vihreä, harmaa, ruskea, (violetti), (oranssi) (Koski 1983:265). In English the basic terms given by Berlin and Kay were: white, black, red, yellow, green, blue, brown, purple, pink, orange, grey (Berlin, Kay 1969:2).

3.1. Berlin and Kay made a number of experiments to find the focal points and the outer boundaries of the basic colour terms. Their subjects were people speaking 20 different languages. This was augmented by the analysis of 78 more languages on the basis of written sources and personal contacts. The choice of languages was a representative one, but for the fact that Balto-Finnic languages were not included; the Uralic languages were represented only by Hungarian, and the Turkic-Tartar family of languages was left out altogether.

At first in a conversation with the informant they tried to find out the basic colour terms in his/her native language (unfortunately this process has not been described in detail). After that they were given a table of 329 colour samples provided by Munsell Color Company and asked to mark on the cover acetate all the chips corresponding to that term, and the best example of that colour. The experiment was repeated three times with a week's interval. 
The drawback of the method was that the subjects of the experiments were mostly extracted from their native language environment and subjected to the influence of the English language (chiefly foreign students studying in the USA). Their constant use of English may have influenced their native colour vocabulary. Many languages were represented by only one informant.

Second, the presentation of colour samples in a table controls to some extent the decision of the test subject. In such a presentation one of the colour domains is inevitably split (in this case that of the red colour), and there is a certain amount of interaction of colours. Evidently the experiment should have been repeated with a different placement of colours, or presenting the samples one by one. One dimension of colour space - saturation was omitted and so the domain of less-saturated colours, brown, pink and grey was diminished. Thus the result was but an ideal model; with a model, however, there is always the danger of over-absolutising the result, and of lefting unnoticed the exceptions. The disadvantages of Berlin and Kay's method have repeatedly been pointed out (e.g. Kuschel, Monberg 1974), but nobody has succeeded in disproving it completely.

3.2. The data of Berlin's and Kay's experiments concerning the foci of basic categories supported their hypothesis of the universality of basic colour terms in different languages. However, they left aside the results of the second part of the experiments - the category boundaries. The main reason was the wide range of variation of the data, which made them unreliable.

There are, however, some interesting points concluded from these results (see Berlin, Kay 1969: Figure 2,3, and Appendix I). First - the most similar or identical foci in different languages were those of white, black and red. These corresponded to one or two colour samples only. These were also the colours that had the best determined category boundaries. Wider, and often also overlapping, were the domains of blue and green, and their foci were not so clearly defined. Similar results about the difference in the range of colour domains were also attained by R. M. Boynton and C. X. Olson, whose tests made use of a considerably larger set of colour samples that were more uniformly divided over the colour space (see Boynton, Olson 1987).

The greatest divergence between different languages seems to arise in the foci and domains of purple, pink and brown. This could also be noticed in the Estonian-language presentations of Berlin and Kay's theory, where the Estonian equivalent for the English purple was sometimes violett (Viires 1983), sometimes purpur (Allik 1982). M. Koski believes the corresponding Estonian term to be lilla (Koski 1983: 233-235).

Purpur in Estonian presumably signifies rather some kind of cool dark red than the bluish-red hue that can be seen as Berlin and Kay's sphere of denotation of the American English word purple. The translations of the English purple e.g. in the French, German, Swedish and Norwegian languages are also derived from the word-stem violet. One of the reasons for these differences is probably the fact that the well-known purple dye of the ancient times could produce a wide scale of different hues from dark red to dark blue. The word-stem appeared in different languages at different times and was borrowed from different sources; the role of the mediator for Estonian, as well as some other languages, has evidently been played by the Bible translations.

The vagueness of the border-area between blue and green, which probably most people have experienced in their everyday life, is one of the coeffective reasons for the changes in the sensitivity of the eye to yellow and blue, depending on the age and geographic location. This phenomenon is caused by the growth of the pigmentation of the retina of elderly people as well as those inhabiting the equatorial areas. Consequently, children and Nordic people perceive green as brighter than aged people and Southerners (Bornstein 1973, Pickford 1972). 
3.3. On the grounds of the comparison between different languages Berlin and Kay concluded that the appearance of basic colour terms in a language follows a certain order where one can distinguish between seven stages:

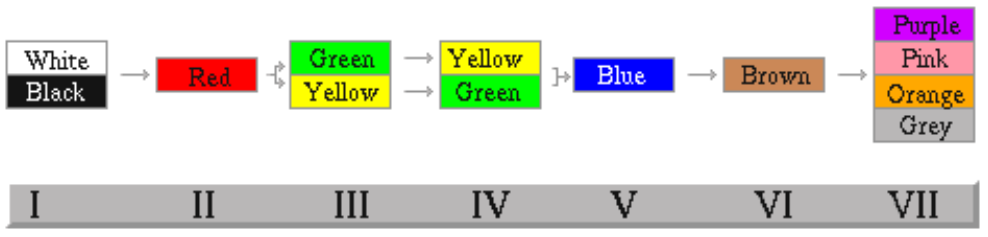

Figure 3. Berlin and Kay's hypothesis about seven evolutionary stages of colour terms (1969:4).

The appearance of black, white and red in the first two stages is reliable, but there may be doubts and controversies concerning the following ones. Especially the coming of green before blue and of grey only in the last grade have not found confirmation in a number of later investigations (cf. Kay, McDaniel 1978; Kay, Berlin, Merrifield 1991). By M. Koski are these the colours that cause the greatest controversies when contrasted with the equivalents in the Baltic-Finnic languages (Koski 1983:260).

3.4. Elaborations of Berlin and Kay's hypothesis (in the first place, Kay, McDaniel 1978) have introduced the notions of composite category and primary category. The latter correspond to the six psychological primary colours. According to Kay and McDaniel, in the first stage one of the colour terms signifies the entire domain of dark and cold colours (the composite category of black, blue, and green), and the other signifies the entire warm and light domain (the composite category of red, yellow, and white). In the second stage, the warm and chromatic composite category is detached from the latter; in the third and fourth stages this is further divided into the primary categories of red and yellow, and the cold-chromatic composite category separates. In the fifth stage all the six primary categories are separated, and in the next stages derived categories are introduced into the language. According to the elaborated variant grey can also appear earlier. Thus the appearance of colour names in a language has become much more flexible.
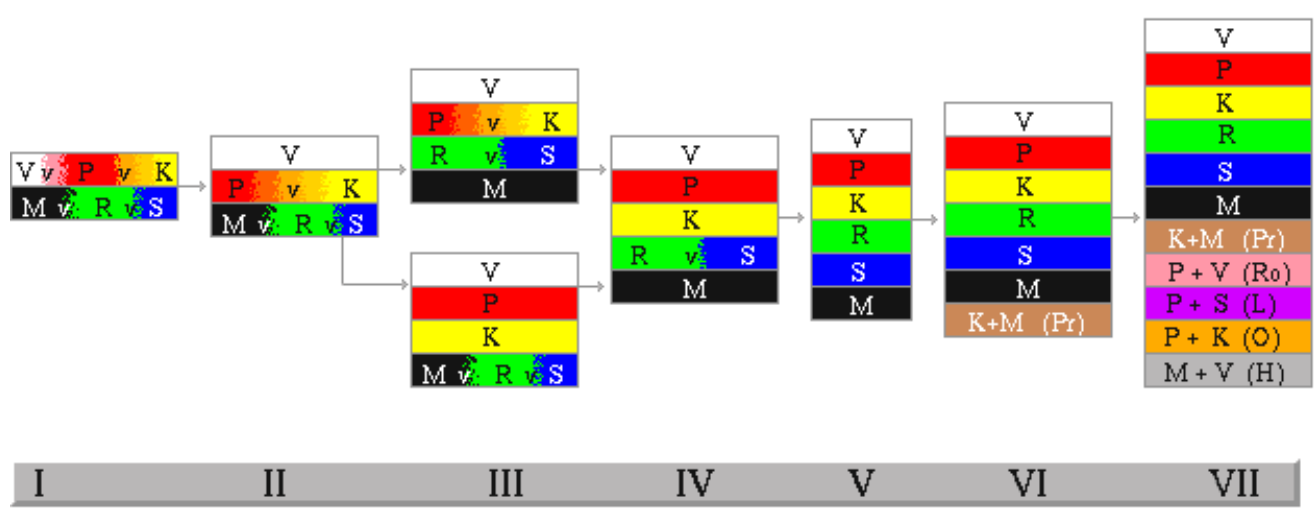

Figure 4. Kay and McDaniel's new interpretation of the evolution of basic colour terms (Kay, McDaniel 1978:639). V - white, P - red, K - yellow, S - blue, M - black, R - green, H - grey, O - orange, Pr - brown, Ro - pink, L - purple, v or; composite category, $\mathrm{V} v \mathrm{P}$ v K means that in that particular language the warm and light colour domain is denoted either by the word white, red of yellow. + - derived category. $\mathrm{K}+\mathrm{M}(\mathrm{Pr})$ signifies the appearance of the word brown, which has been coined to denote the transition stage between yellow and black. 
Perhaps the greatest contribution of Kay and McDaniel's article was that they did not deal with mere focal colours, but with the three-dimensional colour space. However, they disregarded the differences of the colour domains corresponding to different colour terms, and thus the results concentrated on the centres of colour domains only. The neurophysiological explanation of the origin of colour terms was added, which was absent in Berlin and Kay's treatment, and the analysis was conducted with a mathematical method, the fuzzy-set theory. According the Kay and McDaniel, the neurophysiology of colour perception has given rise to (or, to be more exact, the opponent colour perception corresponds to) six (primary) colour terms: black, white, red, yellow, blue, and green. The rest of the basic terms have arisen in the intermediate space between these primary colours. Thus:

pink $=$ red + white

purple $=$ blue + red

grey $=$ black + white

orange $=$ red + yellow

brown $=$ yellow + black

Obviously, the origin of derived categories is the most questionable part of Kay and McDaniel's hypothesis. Especially the last, the development of brown as an intersection between yellow and black, seems to be disputable to anyone who has ever dealt with the mixing of colours, since brown can be obtained by blending various colours. Certainly, brown does contain an element of red. The reason, of course, is also the three-dimensionality of colour space, which enables to place intersections between different domains of primary colours.

It is not clear, why exactly the derived categories developed between those, and not other primary colours. However, they believe that these very derived categories will in the future produce new basic colour terms in the language. This is the explanation for the word goluboi in Russian, a permanent source of discussion; the English words about to become basic terms are believed to include turquoise, lime, maroon, etc. They state that some people already use these colour terms in the role of basic ones. This, however, does not correspond to the fourth condition of the basic colour terms. These words also create some confusion with the second condition: the given colour cannot be marked with another existing basic colour term. Kay and McDaniel came to the following conclusions:

(1) the semantics of color display substantial linguistic universals;

(2) these semantic universals are based on panhuman neurophysiological processes in the perception of color.

Consequently, the authors find that these finding place strict limits on the applicability of SapirWhorf's hypothesis and related hypotheses of extrem linguistic/cultural relativity (Kay, McDaniel 1978:644).

3.5. Not wishing to deny importance of Kay and McDaniel's work, one still should avoid applying their pattern automatically. With every concrete language, one should take into account its particular cultural background, that is to say, to penetrate into the colour terms of that language, or to play over the basic terms from the insider's viewpoint on language. This is certainly demonstrated by the divergence found by Mauno Koski and Ants Viires in the Balto-Finnic languages. Unfortunately, there are no research works as comprehensive as to Koski's into the diachronic aspect of colour terms in some other language families, in the first place, naturally, in the Indo-European languages. 
Second, as a result of the elaboration of the theory, the appearance of colour terms in a certain language has become quite vague, and therefore all that remains is the statement that in a certain stage of development any language has a certain number of basic colour terms. The proof for the first stage is provided by a few primitive languages, and even this proof has been criticised (e.g. Heider 1972). Fairly logical is the second stage with three colour terms. Evidently, the emergence of yellow, blue and green also follows the rule. It still seems that there are too many discrepancies concerning the rest of the colour terms and the order of their appearance is better explained with the peculiarities of culture, with the need to use them (for economic, technological, cultural, climatic reasons) to distinguish between colours.

Third, there is the danger to over-absolutise this temptingly exact scientific-looking theory, for example, by concluding from the number of colour terms in the language, that the speakers are incapable for perceiving or discriminating other colours; or else, to establish the age of a text (folk song) by the number of colour terms used there. It is in no way established that a song should contain all colour terms existing in the language in that particular period; however, there are some general conclusions to be drawn from this. One of the most immoderate examples would be Heino Eelsalu's attempt to date the Finnish and Estonian songs of creation with the help of (Lascaux?) cave paintings (Eelsalu 1985). He assumed that when the cave painters used only a certain limited number of colours, and the names of the same colours can be found in a certain type of folk song, the age of the paintings and the song should be the same. At that time the use of colours depended primarily on the knowledge of colour pigments and their availability. So, almost everywhere the best known and the most easily obtainable have been red, yellow, white and black coloured earth. It is not explained why the language of the cave painters should have had the basic names for these very colours that they used in their paintings. It is also not clear what could have been the relationship between the cave painters' and early Finno-Ugrians' languages.

3.6. And so we can speak about six colour terms, in fact, primary colour terms, the evolution of which is determined by neurophysiology: black, white, red, yellow, blue and green. Their origin is best explained by Berlin and Kay's hypothesis, so that in conclusion we can speak about four stages of development of languages, as far as the basic colour terms are concerned; there seem to be no inconsistencies with respect to these stages:

Stage 1: the language has words to denote black (the whole dark-cold area), white (light area) and red (warm area). This stage can be composed of two steps, i.e. the category of red develops later.

Stage 2: yellow is separated from the composite category of warm, and blue or green is separated from the category of black to denote the cold area (the exact order may vary in different languages). In this stage the word for grey may also come in.

Stage 3: green and blue, grey, and the word denoting the warm unsaturated colour (brown; in Estonian pruun, ruske, ruuge)

Stage 4: the basic terms for other intersections come in.

3.7. In conclusion, we may assume that at least the development of primary colour terms is a twosided process. On the one hand, the categorisation of the colour space into primary colours is determined by the neurophysiology of colour perception. This, however, does not induce the evolution of colour terms unless the corresponding colour finds a sanction, a equivalent in the surrounding environment, i.e. unless there is a "déjà-vu" effect. As is well known, people find pure spectral colours to be the most fascinating and pleasant. A good example may be the orange, which indeed represents the purest orange colour and which in many languages is marked with the same word that is used to denote its colour. Also, red is often derived from the word signifying blood. At 
the same time, nature manifests conspicuously more intermediary stages of blue and green - from the colours of all the different plants to the ever-changing shades of water and skies; maybe for that reason the words are also less stable.

Naturally, every language has a multitude of possibilities to denote colours even if there is no exact basic colour term for that particular hue. To systematise other colour terms (e.g. compound words and phrases: light red, pitch-black; words derived from the names of things/phenomena of some characteristic colour, but still firmly associated with the original meaning: golden, silver, chalky; dialectal words and other abundant colour vocabulary), one would need some kind of classification, since in practical usage it is not merely basic terms that come in one's way.

As a very vague solution, I would offer the following scale of Estonian colour terms, based on the exactness of determination of colours and frequency of usage:

\section{Basic colour terms:}

(a) must (black), valge (white), punane (red) (corresponding to Berlin and Kay's 2nd stage). The association or focal colour corresponding to all three words is the most precise in different languages.

(b) sinine (blue), kollane (yellow), hall (grey). These colours occur frequently in folklore; the association of yellow is exact, that of the others can have some variations. (c) roheline (green), pruun (brown), lilla (purple), roosa (pink) and other more recently coined basic colour terms. Their frequency in folklore is little, as is the determination of the colour with the word. The possible subdivisions here would be better adapted words (roheline - green, pruun brown) and later borrowings that still sound somewhat unfamiliar in the Estonian language.

II. Non-basic terms. A rich vocabulary of compounds, associations and dialectal formations (as well as variants used only in limited contexts). This division certainly requires various subdivisions, but this would not fit within the limits of the present work.

Any degree of systematisation of colour vocabulary in the Estonian language would be welcome, for nearly everybody has experienced confusion created by mutual misunderstandings in the meaning of a certain colour term, especially when used by people of different walks of life. The need is even more serious in the specialised literature, such as the natural sciences, where it is often necessary to convey the colour exactly through words.

\section{Colour Terms and Associations}

4.1. The colourfulness of our environment is our everyday experience, and, as it is with customary things, we tend to forget about it. We notice in the first place those colours that stand out from their background, that strike us as somehow extraordinary. This explains the frequent use of red, black and white (the colours of the first division) in folk poetry and literature - they are associated with the extraordinary rather than the ordinary, and they automatically attract attention.

First, the opposite white and black, which are mostly associated with light (valge, the Estonian for white, is a polysemantic word, meaning both 'white' and 'light') and darkness, further with day and night. These meanings play an unavoidably important role in all cultures of the whole world. The secondary association is with cleanness and dirtiness (Estonian word must has also two meanings 'black' and 'dirty'). The aspect of judgement, good-evil, which is predominant in Christianity (in the Bible since the myth of the Creation) and in the German popular culture, seems to be weaker here; something ominous is rather associated with the word hall 'grey'. Nevertheless, the pair lightdarkness does convey some kind of judgement, since night has always struck human beings as more terrifying than day. 
The neutral pair black-white is opposed to the highly chromatic red. The attention paid to the red colour by probably every culture has several mutually contributing causes: (1) The visual sensation of the red colour has psychologically the most powerful stimulating effect.

(2) As the complementary colour to the cold green, red stands out the most sharply from its surrounding nature. At the same time the red colour is very rare in our geographical zone, which gives the colour the required uniqueness.

(3) Finally, the association with blood has an especially strong psychological power, as has that with fire and the rising or setting sun.

On the grounds of the above reasoning we can conclude the fairly significant role of white, black and red in our popular culture, and possibly in the whole human culture.

4.2. At this point I should make some remarks. First, there is Jaan Puhvel's reasoning from his Comparative Mythology (1987:159ff.). He speaks about the crucial role of the tricolour red-whitegreen in the Indo-European cultures. So, in ancient Rome the participants of the chariot race at the New Year celebration were divided in three "tribes", who wore clothes of those colours. Further, Puhvel hypothesizes that red, white and green or blue were the canonised colours of the three classes of Indo-Europeans (there are traces of their presence among nearly every Indo-European nation): white was the colour of priests, red that of warriors and green or blue the colour of the productive class. He sees the significance of the combination for Indo-Europeans in its continuation in the colours of flags of many states (Italy, France, the Netherlands, Norway, Ireland, Great Britain, the United States).

For J. Puhvel this contemplation is rather a side issue and he gives no precise explanation for the hypothesis, therefore there is no reason to dwell on it. The connection with the state colours is somewhat questionable, because it is simply an attractive combination and each flag has a different history. For example, the Norwegians just inserted a blue cross into the Danish flag, to distinguish themselves from the Kingdom Denmark in such a prosaic way.

Another remark pertains to the colour symbolism in general, which I am inclined to deny in its conventional meaning (à la blue means this and yellow means that). The colours do have a certain sphere of associations, as we have seen with red, white and black. The association may have an etymological, cultural, natural or personal explanation (see also: Allik 1982, Pickford 1972). The colour terms themselves are often polysemantic. The colour as a sign that can be interpreted unequivocally can exist only in a closed system, a definite cultural tradition, where all members would understand it identically - for example, the Catholic liturgy, the iconography of a certain period in the history of art, certain kinds of Chinese and Japanese theatre. In art a colour can be in the function sign only when the nature of the art of that particular period aims at encoding, not depicting the surrounding world, that is, principally at the periods when and in the countries where deep religious attitudes prevail. There have never been any comprehensive metacultural symbol systems, except, perhaps, the above-mentioned universal associations of black, red and white (and even these depend on the context in their functioning). The main reason for this is probably the poor capacity of abstraction of colours, which was mentioned above, but definitely also the indiscreteness of colours. The discreteness in a colour space is not created by the focal points of the primary colours, i.e. discrete points that are connected with each other by indiscrete transition areas. In a similar way, we cannot say that a sound of a certain pitch should symbolise a particular idea.

4.3. We are not surprised at our daily awakening, washing, and other day-to-day routine. Such actions are rather mechanical, automatic, one need not be mindful of them. This is the reason why in the folklore archives the greatest number of reports concern such customs that seem somehow 
different from the ordinary life - birth, weddings, death - or activities that are familiar but take place after a lengthy interval, e.g. on St. George's Day, at harvest time, or at the beginning of autumn. Everything concerning diseases and magical actions is also quite novel and worth mentioning. But colours surround us from morning till night, and therefore it is only on extraordinary occasions when they are somehow striking that a human being is mindful of them. For example, unusual atmospheric phenomena, rainbow, sunset; also activities directly connected with colours such as cloth or yarn dyeing, but also the necessity to disguise oneself or, the other way round, to stand out from the surroundings. In the latter case the best way in our Estonian green, dirty of snowy landscape and against grey buildings is to apply the red colour. And finally, colour is one of the most suitable methods in analogy magic: red as the allegory for blood, the utilisation of yellow plants a. o. to cure hepatitis, etc.

\section{Red}

The following analysis is focused on the red colour, or on the most typical examples of its traditional usage in customs, clothing and folk songs. To explain why namely this colour is chosen, it is possible refer to the afore-given reasoning about the most exact definition of red in the colour perception, and perhaps to the fact that in custom accounts the most frequently mentioned colour is red. It would over-expand the article if we discussed all colours here, moreover, this would require the inclusion of all colour combinations. Therefore, let red be here one of the most handy and convenient examples, a paradigm for others.

\subsection{The Historical Background and the Neighbouring Cultures}

If we leave aside the late Palaeolithic custom in Southern Europe and among many American Indian tribes to colour the dead bodies red with ochre (obviously a replacement of blood sacrifice), in the cultures of the antiquity and, moved by these, in early Christianity the use of red has been mostly influenced, besides the association with blood, by the valuable purple dye. Its value explains also the purple colour of the Roman Emperor's robes. The high esteem of purple gowns was then, of course, transferred to the Occidental cultural tradition. Another important colour of clothing in the antiquity was crimson. This was the colour of the Roman soldier's uniform, where we might assume attempts of certain psychological effect on the enemy, especially in the close combat. Thus, the purple coat given to Christ in the gospels according to Matthew, Mark, Luke, and John was nothing but an ordinary Roman soldier's coat, which was changed into purple as a result of the development of the image of Jesus on the throne. There are many references to red and purple clothes in the Old Testament (in the first place, the instructions for making the tabernacle and the priests' robes). Also, we can find instructions to sacrifice red yarn after being purified from leprosy (real or suspected). For example:

"... then the priest shall order that two pure living birds shall be taken for him who is purified, and cedar wood, scarlet yarn and hyssop." (Leviticus 13:4).

In the New Testament and in early Christianity the red colour is primarily associated with the blood sacrifice of Christ and the martyrs and with the red wine of the Eucharist. In the Middle Ages, up to the Renaissance, purple was condemned as too luxurious and it was used only for cardinal's robes.

If we compare the Russian and German traditions, both of which have exerted the greatest influence on the Estonian newer folk culture, one of the most striking features is the parallel meanings of the word krasnyi, 'beautiful' and 'red', that were there as late as in the 15 th century. Thus in the Russian language and doubtless also in the traditional rites red has had an established positive connotation. 
In the German folk culture such connotation is not so conspicuous. The numerous folk beliefs and customs connected with the red colour are rather of a menacing character; this is probably the result of the condemning attitude of Lutheran and other sectarian doctrines towards the earlier traditions.

The most common association is that with blood, principally in a wide variety of customs connected with red yarn, string, thread. They suggest a considerably richer imagination than the analogical Estonian examples. Let us take the following description as an example. The Pennsylvanian Dutch tie a red string, brought from a shop without having had to pay for it, around a thimble with a spider in it; this is hung over the bed of a child suffering from whooping cough. A remedy for tonsillitis and diphtheria is to tie around the sick person's neck a red string, with which an adder has been strangled (Hoffmann-Krayer 1935, sub Rot). It was a common practice to tie red yarn about the ailing part of the body, whether it was a swollen leg or whatever.

Red yarn was also a part of fertility magic (for instance, in Austria Minor people used to tie red bands around fruit trees on Shrove Tuesday; similar bandages were also tied around the last sheaf, etc.) and it played an important role as protection against the evil eye.

As was mentioned, the use of red yarn has already been referred to in the Bible, and it seems to be widely accepted by nearly all nations, therefore it is difficult to speak about the immediate sources of borrowing.

Close to the practices with red yarn is the use of red details of clothing. This colour, usually a preventive measure against all evil, plays a significant part all over the German-inhabited world, especially in the wedding customs. So, the bride's costume included red stockings, a red bridal veil or some other item. At the same time, there are also reports about the use of red in burial traditions and, to the contrary, its prohibition in bridal costumes, since red was said to attract lightning (ibid.)

In fertility magic red-painted Easter eggs were very important. These were given to children by their parents and godparents; the eggs were buried in the middle of the field on Maundy Thursday, or put into the first sheaf, on Easter eve young girls sent these eggs to the boys, to attain their love. In preventive and protection magic the practice of painting the doorjambs red and the use of all kinds of plants with red fruit were also significant (ibid.) The red colour of the berries could also be one of the explanations why the rowan-tree was attributed magic qualities.

Another association of the red colour in the German traditional beliefs is with fire, flame and lightning. These are connected with red animals - above all, naturally, a red cockerel, but also fox, squirrel, red cat, bullfinch and redstart. The thunder god Donar had red hair and red beard, and redfurred animals were thought to be Donar's sacred animals. People believed that red animals, plants and things would attract lightning. As is often the case, in places the belief is quite the other way round - these were said to protect you from lightning.

In Christianity Donar merged with the devil, who then inherited also his red colour. It is the German devil, and not our Estonian Old Nick, whose attribute, besides the black coat, is often a red one. Further there was the belief that the people who tied red yarn around their bodies had sold their souls to the devil. And red yarn and ink were also used in the genuine black magic. One may remember that a contract made with the devil had to be signed in blood or red ink. Rivers and creeks with red water, or red stones were dangerous, since they indicated a site of murder. Red skies or a red spot on a child's skin seemed ominous; finally, we should remember the common mistrust towards red-haired people (ibid.).

In brief, in German tradition the red colour was attributed intermingled, fertilising and generative, protective and preventive, altogether controversial powers, and it has always been associated with a characteristic thing of phenomenon, especially with blood. The positive or negative disposition of 
red has also depended on the role attributed to its wearer - it was either good or bad, regardless of the qualities of the abstract colour.

\subsection{Estonian Beliefs and Customs}

Almost all of these customs of German folk tradition can also be found among the Estonians. First, the red string: a widespread remedy against swelling when tied around the foot, or tied around a woman's body after a substantial loss of blood at delivery, around a baby's neck to ward off diseases, etc (E 860 (34) < KJn; ERA II 7, 87 (25) < Mär; ERA II 6, 182 (25) < Rap; ERA I 4, 59 (11) < Hls; here and subsequently are given only some relevant examples). It seemed that the practice of offering red strings and pieces of yarn was very universal. The custom of tying these to trees has been mentioned as late as in the 17th century by Olearius (Loorits 1951:354; 1960:75). The Livonians used to offer red yarn to the Mother of the Marsh when going to pick berries, and to the water sprite before fishing (Loorits 1926:108,115).

So, in general red string has functioned as a neutral or even positive aid in Estonia, malevolent sorcery is not so common in this connection. Red string has been widely used in wedding rites, for example it was tied to the matrimonial bed, around the match-making wine bottle or staff (E 45636 (6) < Trv; RKM II 1, 147 (1) < Pst), cast on the way of the wedding procession or tied across the road before the procession passed (H II 33, 648 (41) < San; Hupel 1777:182-183). After arrival to the bridegroom's house a young wife tied red strings, girdles or red-trim mittens to the "strategic" places: into the cattle-shed, to the bed, etc., where they were to ensure fertility to her future actions (E 23356/7 < Hls; E $25615<\mathrm{Hls}$ ). It was thought good if the dowry included many red mittens and girdles (H II 43, $230(79)<$ Pst; E $16988(157)<$ Hls). In general evidently it was the red colour that was important, and not so much the thing, whether it was a girdle, a mitten or a piece of yarn.

Quite a number of customs were connected with blood. so the cheeks of a new-born baby were smeared with the blood from the navel, so that these might be rosy (E 81029 (30) < Jäm; RKM II 75, 605 (4) < Mus). This section includes also all customs connected with menstrual blood.

There are also magical practices of analogy that are not based on the association of the red colour with blood: the prohibition of sexual intercourse under a red blanket or at dawn, so that the child might not be red-haired (E 48686 (65) < Vil; ERA II 200, 281 (9) < Mär). Also, a pregnant woman was not to see animal slaughter or fire. A red mark of fire on the child's body can be an omen that this person will die of fire. The association of red with fire is, of course, negative, and likewise is it in the German tradition. This is a rule that is universal with all colour associations. The relations with the pure or focal colour (the best example of that particular colour) are usually positive, while deviations and blurry tones cause unpleasant responses. As the focal colour of red is the closest to the colour of blood (or slightly deeper), the colour of fire is a deviation. The association is further strengthened by a fear of fire as an especially serious catastrophe.

Next some allusions to the application of red colour in clothes. It is not quite certain, but the skills of cloth-dying reached Estonia probably in the 13-14th centuries. The loan-words värv 'colour, dye' and värvima 'to dye' date back to the same period. There is a comprehensive survey of the vocabulary connected with dying by A. Viires (Viires 1983). The first cloth dyes were the red of crosswort, the black of meadow ore, and probably some hues of yellow and green. Red details have been quite characteristic in the Estonian folk costumes and, at the same time, the predominant items of decoration, especially before the spread of industrial dyes until the 18th century. The use of aniline dyes brought about a further spread of red. 
Manninen has pointed the very common Estonian red decorations partly as an instance of Russian influence (1927:191 etc). However, keeping in mind that the beliefs connected with red strings and girdles, and, especially, red details of clothing, are distributed evenly among all Finno-Ugric peoples, as well as in Scandinavia, it can be considered a common North European tradition.

The most characteristic and perhaps very ancient features of Estonian folk costumes are red borders around the collar of the long coat and on the lower edge of the skirt. The covering or omission of red details in one's clothing was the most conspicuous sign of mourning (Manninen 1927:64, 76, 100, 102-103, 193, 264; Vilberg 1939). On the isles there are specific rules and prohibitions governing this field, and for instance in Kihnu these are still in force. A young girl has to wear a red skirt, while an old woman who has lost many relatives wears a darker skirt with more blue stripes in it. There are reports of similar rules from mainland Estonia, although not so strict (Vilberg 1939).

At weddings people wore even more red than usual. There are numerous examples illustrating this rule: the red wedding aprons of the bride and her maids of honour and the red-ornamented headdress of the first day at Muhu; red wraparound skirt of the bride at Mulgi and Saaremaa; maiden's wreath that was always covered with red in South Estonia as well as on the isles and that later developed into a bridal head-dress on the isles; the red bridal winter cap (although red-topped winter caps were very common in general); red wedding plaids at Halliste (Manninen 1927; Vilberg 1939; RKM II 17, 139 (24) < Tõs). A number of former universal red items of clothing survived in the bridal dress.

At the same time, at funerals and in the period of mourning people tried to avoid red details in their clothing; one may say that this prohibition was almost the sole indisputable colour symbolism in the older folk costume. We may suppose that this was an attempt not to attract the attention of the world of the dead, to hide oneself (a very thorough treatment of this problem is K. Vilberg's seminar paper on ethnography from 1939).

\subsection{The word red in the Estonian folk songs}

As the last issue it is discussed the occurrence of red as a word, a name for a colour, in the folk songs. First, the etymology of the word, according to M. Koski. The word is of Finno-Ugric origin, the original meaning being puna - 'hair, fur', which is still present in the Volgaic and Ugric languages. Its parallel meaning came to be 'the colour of the hair or fur', and so the development was:

puna $_{1}$ - 'hair, fur'

puna $_{2}$ - 'the colour of the hair', hence the adjective punane - 'of the colour of the hair'.

The Proto-Finnic language borrowed the Baltic word karva, which also developed a dual meaning karva $_{1}$ - 'hair'

$k_{\text {arva }}$ - 'the colour of the hair'.

As the word karv substituted for the word puna $a_{1}$, there was no reason to use the meaning puna, and the word adopted the form punane/punainen as the standard form, retaining the exclusive meaning of a colour term among the western Baltic-Finnic peoples. 
Other Baltic-Finnic languages have the following equivalents for the Estonian literary (and North Estonian and Mulk dialectal) form punane: Finnish punainen (Agricola has also ruskea), Ingrian punnain, Livonian pu nni, South Estonian verev, Votian kaunis (Kukkose dialectal punain(A)), Karelian ruskie (Aunus dialectal rusgei), Lydic rusked, Vepsian rusked (in the southern and some central dialects käbed) (Koski 1983:64 ff.; SKES sub: punainen).

The following review exhausts by no means the use of the word red in alliterative folk songs; rather is the purpose to point out some interesting facts. The material has been taken from the published collections of folk songs. Eliminated are all combinations of different colours containing red (the most frequent being red-white, red-blue, red-blue-golden/yellow), otherwise the study would be too complicated.

The theme of colour combinations is certainly worth a thorough study, as it introduces remarkable shifts of meaning. For example in the pair red-blue these colours most frequently symbolise contrasted qualities - red signifies the good, familiar, beautiful, while blue is unfamiliar and evil. At the same time there are plenty of cases where the colour blue repeats and emphasises the positive assessment given by red, or those where the same pair signifies first the positive and then in the repetition the negative. For example, there is a quite well-known end of song with the description of the burial sites of a maiden (or some other positive hero) and a dark man/boy/attacker: on the maiden's grave The earth was red with strawberries/ the bog was blue with insects, while on the boy's grave The bog was blue with snakes/ the earth was red with beetles. So we can conclude that the connotations attached to a certain colour cannot be mechanically transferred to a combination of colours.

The occurrence and description of the Estonian names of colours has been studied repeatedly since the 1920's (there are several seminar papers on folklore studies that registered the colour terms within certain publications); later the use of the names of colours has been studied primarily by $\mathrm{T}$. Roll (Roll 1985, Roll 1990). And yet we may say that the studies have not progressed from the stage of description and there is no deeper analysis; or else, the authors have went to the other extreme, presenting fanciful hypotheses. Neither is the present paper an attempt to fill the gap, it is rather a laconic reference.

I have primarily focused on fixed epithets, which obviously are the best expressions of the mental associations created by the word red in popular tradition.

The most evident correlation is red-beautiful, and it seems to be the most frequent one, too:

Peremees, peremehekene ütlid mind leivasta lihava ütlid viinast mind verevi ütlid saiasta saleda ütlid pudrusta punase (EKS $4^{0} 5,89(1)<$ Tarvastu)

Keskel see pere punane (ER1A III 1: Variant $3688<$ Vig)

Ilusad punased neiud Pretty red maidens

Master, dear master, Thou said from bread I'm healthy, Thou said from wine I'm ruddy, Thou said from white bread I'm slender, Thou said from porridge I'm red.

In the middle this red family

(ER1A III 1: Variant 4154) 
Küll on mehi meie vallas ilusaida, heledaida, punaseida, priske'eida (VK VI 1989: Type 692.)
Lots of men in our parish, handsome, fair, red, healthy

Even when the described person wears a red item of clothing, the meaning 'beautiful' is extended to signify the person as a whole:
Maria, punane kuube
Mary with a red coat
sie minu ema õlese this is my mother

(ER1 1926: $110<$ Jõh, "Mareta laps")

In this context the colour has acquired an abstract character and an additional meaning. This is proved first of all by the fact that items of other colour are hardly ever mentioned; the content of the song also refers to such an appraisal.

Red seems to lack the very intensive positive connotation that goes with white:
Meie küla nuored mehed, meie valla valged poisid The young men of our village, (ER1A III 1: Variant $3659<$ Jõh)
Vigalas on mehed valged
The men of Vigala are white
Virumaal on mehed mustad the men of Virumaa are black

(ER1A I 1: Variant $405<\mathrm{Kad}$ ).

White is most frequently used to denote 'beautiful and good', with red the aspect of goodness seems to be weaker, it has a more neutral effect and refers primarily to the beauty. The strongest positive association is conveyed by the word golden. In fact, this word is never used in the negative meaning, except in the context where wealth as such has been denounced.

Red conveys negative association only when it directly implies blood. It occurs often in curses:

Üks nisa jooksku verda,
teine nisa jooksku vetta,
kolmas piimada punasta,
neljas vahtu valgeeda!

Let one teat milk blood and the second one water the third teat red milk and the fourth white foam!

(ER1 1926: 398 < Kad: "Müüdud neiu")

The word puna 'red colour' can be a straight synonym for 'blood': Kõik iks veerü su verele/ kõik iks puhe su punalõ (SL 1904: No. 189 - warning of the maiden in the Song of Thomas). It may also be a contamination with white and a reference to beauty: Ju puna minust pugenud / ju valge minust vajunud (Red has disappeared from my face / white has left from my cheeks) (ER1A I 1: Variant $431<$ Kos: prayer to the north wind).

The magical associations of the word red, pointer out by T. Roll in connection with some fixed epithets (Roll 1990:36), are in the folk song not so obvious as, for instance, in the case of red details 
in folk costume or red string in folk belief in general. The magical function is perhaps connected with some fixed verbal images, but it is too obscure to observe it closely. In other words, the word red and the red colour of an object function in different ways.

A quite frequent conjunction in addition to the above mentioned praise of a maiden or a young man is a red horse, which usually appears in gradation coupled with other colours.

Viis oli alli tal eesse, kuusi kure karvalista, seitse sirget punasta

(ERl 1932: $48<$ Vil: "Jeesus, Maria, Madli").
He had five greys harnessed, six stork-coloured, seven straight red ones.

A connection with trees, again probably with the implication of 'beautiful', although it may also be an indirect reference to the magical meaning:
Poolamaa puu punatse, punatsem on meie venda
The trees of Poland are red, our brother is even redder.

(ER1 1926: $241<$ Saa: "Uppunud vend")

One of the most interesting conjunctions is the combination of red and sea:
Purjetan punasta merda
Sailing the red seas
(H II 15, 56/7 (5) < Kuu; H I 5, $94(297)<$ Hlj)

While the red sails may be a reference to the Viking Age when, at least in Scandinavia, the sails were indeed red or red-striped, the connection with sea is quite intricate. There are different opinions whether red sea should be capitalised or not. The allusion to the real Red Sea, however, seems to be secondary. T. Roll's statement that red was to imply the dangers of the deep sea seems also dubious, because otherwise such "creative aspirations" should be present in other connections as well (Roll 1990:33).

The South Estonian word verev 'red' cannot be ignored. The earliest mentions of the word were made by J. Gutslaff in 1648 (werriw) and the New Testament in 1727 (first edition 1686): läbbi werrewä Merre (He 11, 29; Ap. 7, 36). Relying on A. Saareste's Eesti keele mõisteline sõnaraamat (Thesaurus of the Estonian Language), M. Koski puts forward the hypothesis of the expansion of the word punane, especially into the Mulk dialect (parallel usage of different words in different connections). Koski believes that the word verev should be so old that it filled the gap in the basic colour terms. So it had to take place at the time when the North Estonian and Finnish vernacular took up the variant punane, otherwise it should have ousted the existing punane (Koski 1983, $79 \mathrm{ff}$.) Taking into account the frequent parallel usage of both words in the Seto dialectal area, the latter variant seems quite veritable.

It seems to me that verev carries a much stronger emotional charge than punane, and primarily because of its obvious connection with blood. In general it appears in the same phrases as the word punane 'red'. Very typical is also the meaning verev 'red' - 'beautiful': uibohõ ilusahõ/ verevähe vislapuuhõ (into a beautiful apple-tree, on a red cherry-tree) (SL 1904: No. 3); Velo võtt iks verevä naaze (Brother married a red woman) (SL 1904: No. 232). Verev is also used as a synonym for horse: Küsse esält hobõsta, küsse velelt verevät (I asked father to give me a horse, asked my brother to give me a red one) (SL 1904: No. 45). 
Alongside with red, the Seto songs convey the meaning of beautiful, for instance in the description of clothes, mostly with blue details; especially desirable seems to be a shirt of blue:

Olli seläh sinisärki He wore a shirt of blue

(SL 1904: No. 12).

And still red retains firmly its position as a synonym for 'beautiful':

Olli mul ütsi väiko vello, I had a little brother, väiko vello, verrev küpär a little brother, a red-hat

(SL 1904: No. 72).

There are, though, fixed epithets where even the Seto songs use punane. One of the most typical examples is puu punanõ 'red tree':

Niit ta maid maranaidzi, niit ta puid punatsid

(SL 1904: No. 139, especially in the descriptions of haymaking),

and ollu punanõ 'red beer':

All on hiiva, pääl on vattu, Beneath there is yeast, above there is foam, keskeh oll ollu punanõ in the middle is red beer

(SL 1904: No. 104).

The stem puna has also retained the meaning 'blood':

Veri siis vällä veerünese, Blood then burst out, puna maale puttunese red was spilled on the ground (SL 1904: No. 96).

So it seems that punane has a fixed position in some phrases and verev in others. In songs, particularly in South Tartumaa and Viljandi, these words can often occur in repetitions, complementing each other:

It may be either a loan from the northern dialects, as shows the wide distribution of these fixed epithets, or the parallel usage of punane and verev in South Estonian dialects. At this point we should mention M. Koski's reasoning about the use of the word punainen 'red' in

Karelian folk songs. In the Karelian language the most usual word for 'red' is ruskie, but in the folk songs the most frequent word is punainen. Koski tries to find out whether it is an archaism or a fennism. Relying on M. Kuusi's Sampo-eepos. Typologinen analyysi (1949) and his analysis of individual clichés (Koski defines a cliché as a word with the traditional fixed epithet), Koski is inclined to corroborate the last version. It is remarkable, however, that the clichés with punainen in Karelian folk songs are much the same where in the Seto songs use punane. 
First, olo punainen 'red beer': Keskellä olo punaine (in the middle red beer) (SKVR I: 2, 744). (Puna-stemmed words marking the colour of beer have been used in all Baltic-Finnic languages.)

Next, puu punainen 'red tree' - for instance in the internationally known Song of the Great Oak this phrase is used all over Karelia:

Juurilla tulisen tammen,

Äkähillä puum puna ${ }^{\text {sen }}$

(SKVR I: 4, 855).

Next, veno punainen 'red boat', kala/lohi punainen 'red fish/salmon', and purjehti punaista merda punaisilla purjehilla 'sailed the red seas on red sails', and puna as a synonym for blood:

Puutu veri vuotamasta,

Punanen putuamasta

(SKVR I: 1, 287).

Koski finds that in folk songs puna(inen) in the first place takes up a positive descriptive role, and the function of the relevant clichés is decorative or magical, rather than informative. The Karelian puna(inen) -clichés come from different influences and periods (Koski 1983, 69 ff.). Probably the same conclusion can be drawn about punane in Seto songs, although this does not explain why in some clichés there is punane, and in others verev.

Another moment of interest is the Votic word for 'red', kaunis, that in the newer usage does not have the meaning 'beautiful, pretty', which it has in other Baltic-Finnic languages. And yet this meaning is known to have been there in former times, and in folk songs these words also appear in their original meaning - punainen 'red' and kaunis 'beautiful'. At the same time the Votic language has a number of puna-stem verbs. Koski believes that this evident shift of meaning of the word kaunis 'beautiful' > 'red' is clearly an influence of the Russian language. The case is the same with the Vepsian käbed, which usually denotes 'beautiful', but in the southern and occasionally also in central dialects it means 'red' (Koski 1983, 81 ff.).

Although Russian influence in this shift of meaning is definitely crucial, the above examples show that the association between 'red' and 'beautiful' was not entirely unknown in the Baltic-Finnic languages. Therefore the influence of the Russian language could only intensify the predisposed development.

As a concluding speculation one might analyse the cleft in the present post-socialist Estonian subculture, where the traditional (subconscious) meaning red = beautiful has been displaced by the later red $=$ socialist . Displaced for good and in the Freudian sense, because the attempts to avoid the red colour wherever it may be given a symbolic interpretation can constantly be felt everywhere. Thus the Votian locution kauni aikan - 'in the red, i.e. socialist times' sounds especially tragicomic.

\section{Conclusion}

1. The primary colour terms (red, blue, yellow, green, black, white) are very strongly motivated by the neuro-physiological act of seeing and they function as linguistic universals. The appearance of 
other basic colour terms (brown, yellow, orange, violet) in a language is of more occasional character and influenced by a number of different factors.

2. The foci of black, white and red are the most precisely determined. Their connotations, motivated by a number of mutually supporting factors, are also most firmly fixed in human minds.

3. The role of the red colour in the Estonian folk belief and traditional costume is quite remarkable; red details have often been used, primarily in wedding clothes, and the other way round, they have been avoided at funerals and in mourning. So one may say that at least in the Estonian tradition red conveyed generally a positive magical meaning.

4. The word red occurs in the Estonian runic songs mostly as a fixed epithet, and not so much to denote a colour, but rather in the meaning 'beautiful' (except as a direct reference to blood), expressing usually a positive assessment. A magical connotation is also probable.

Translated by Kai Vassiljeva.

\section{References}

Allik, J. 1982. Värvitaju, värvinimetused ja värvisümboolika. Looming, nr. 3, 378-84.

Allik, J. 1989. Goethe, Hering ja Land: väljakutse establishmendile. Akadeemia, nr. 3, 473-492.

Arnheim, R. 1974. Art and Visual Perception. A Psychology of the Creative Eye. Berkeley:

University of California Press.

Berlin, B.; Kay, P. 1969. Basic Color Terms: Their Universality and Evolution. Berkeley:

University of California Press.

Blonsky, M. (ed.) 1985. On Signs. Baltimore, Maryland: The Johns Hopkins University Press.

Bloomfield, M. 1933. Language. London: George Allen \& Unwin.

Bornstein, M. H. 1973. Color vision and color naming: A psychophysiological hypothesis of cultural difference. Psychological Bulletin, Vol. 80, 257-285.

Boynton, R. M. 1975. Color, hue and wavelength. Handbook of Perception. Eds. E. C. Carterette, M. P. Friedman. Vol. V, Seeing, Chapter 9. New York: Academic Press.

Boynton, R. M.; Olson, C. X. 1987. Locating basic colors in the OSA space. Color Research and Application, Vol. 12, 94-105.

Boynton, R. M.; Fargo, L.; Olson, C. X.; Smallman, H. S. 1989. Category effects in color memory. Color Research and Application, Vol. 14, 229-234.

Butcher, S. H. 1951. Aristotle's Theory of Poetry and Fine art. Dover.

Conklin, H. C. 1973. Color categorization. American Anthropologist, Vol. 75, 931-942.

De Valois, R. L.; De Valois, K. K. 1975. Neural coding of color. Handbook of Perception. Eds.

E.\&nbspC. Carterette, M. P. Friedman, Vol. V, Seeing, Chapter 5. New York: Academic Press.

Eco, U. 1976. A Theory of Semiotics. Bloomington: Indiana University Press.

Eco, U. 1985. How culture conditions the colours we see. On Signs, Ed. M. Blonsky.

Eelsalu, H.; Stöör, Ü. 1984. Looduse värvid ja loomise lugu. Eesti Loodus, nr. 3, 156-58.

Eelsalu, H. 1985. Ajastult ajastule. Tallinn.

Eisen, M. J. 1919. Eesti mütoloogia. Tartu.

Eisen, M. J. 1927. Eesti vana usk. Tartu.

ER1 = Eesti rahvalaulud Dr. J. Hurda ja teiste kogudest. I-II. Tartu, 1926, 1932.

ER1A = Eesti rahvalaulud I-IV. Toim. Ü. Tedre. Tartu, 1969, 1970, 1971, 1972, 1974.

Handbuch der Psychologie. Bd. III, Entwicklungspsychologie. Göttingen, 1959. 
Heider, Eleanor R.(osch) 1972. Probabilities, sampling, and the ethnographic method: The case of Dani colour names. Man, Vol. 7, 3, 448-466.

Hoffmann-Krayer, E.; Bächtold-Stäubli, H. 1935. Handwörterbuch des Deutschen Aberglaubens.

Bd. VII, sub. Rot. Berlin-Leipzig.

Hupel, A. W. 1777. Topographische Nachrichten von Lief- und Ehstland II. Riga.

Gipper, H. 1964. Purpur. Glotta, Vol. 42, 1-2, 39-69.

Irwin, E. 1974. Colour Terms in Greek Poetry. Toronto

Jääger, M. 1992. Lipulaul. Eesti Ekspress, nr. 12 (125).

Kammal, U.; Tihase, K. 1978. Disain. Tallinn.

Kaplinski, J. 1979. Keelekorraldus ja keelekorratus. Sirp ja Vasar, 26. jaan. (nr. 4).

Kay, P.; McDaniel, Ch. K. 1978. The linguistic significance of the meanings of basic color terms.

Language, Vol. 54, 3.

Kay, P.; Berlin, B.; Merrifield, W. 1991. Biocultural implications of systems of color naming.

Journal of Linguistic Anthropology, Vol. 1, 1, 12-25.

Koski, M. 1983. Värien nimitykset suomessa ja lähisukukielissä. SKS Toimituksia 391. Savonlinna.

Kuehni, R. G. 1981. Notes on color terminology in the "Iliad" and the "Epic of Gilgamesh". Color

Research and Application, Vol. 6, 4, 233-236.

Kuschel, R.; Monberg, T. 1974. 'We don't talk much about colour here': a study of colour semantics on Bellona Island. Man, Vol. 9, 2, 213-42.

Livingstone, M. S. 1988. Art, illusion and the visual system. Scientific American, Vol. 258, 1, 68-

75.

Loorits, O. 1926. Liivi rahva usund I. Tartu.

Loorits, O. 1939, 1941. Endis-Eesti elu-olu I, II. Tartu.

Loorits, O. 1949, 1951, 1960. Grundzüge des estnischen Volksglaubens I, II, III. Lund.

Manninen, I. 1927. Eesti rahvariiete ajalugu. Tartu.

McNeill, N. B. 1972. Color and color terminology. Journal of Linguistics, Vol. 8, 21-33.

Norman, R. D.; W. A. Scott 1952. Color and affect: a review on semantic evolution. Journal of generative Psychology, Vol. 46, 185-223.

Otte, H. 1883. Handbuch der Kirchlichen Kunst - Archäologie des deutschen Mittelalters. Leipzig.

Parmasto, E. 1982. Mitmevärviline maailm. Looming, nr. 3, 375-377.

Pickford, R. W. 1972. Psychology and Visual Aesthetics. Hutchinson Educational.

Piibel 1989. Helsinki: Soome piibliselts.

Puhvel, J. 1987. Comparative Mythology. Baltimore, London.

Randlane, T. 1975. Värvirikkus loodusest. Eesti Loodus, nr. 7, 427-29; 8, 478-80.

Rosch, E. 1973. Natural categories. Cognitive Psychology, Vol. 4, 3, 328-350.

Rosch, E. 1975a. Cognitive representations of semantic categories. Journal of Experimental

Psychology: General, Vol. 104, 3, 192-233.

Rosch, E. 1975b. The nature of mental codes for color categories. Journal of Experimental

Psychology: Human Perception and Performance. Vol. 1, 4, 303-322.

Roll, T. 1985. Värvusnimetused ja nende kujundiline osa regivärsilises rahvalaulus. TR $\ddot{U}$

Toimetised 699, 34-57.

Roll, T. 1990. Epiteet eesti regivärsilises rahvalaulus. Väitekiri, Tartu Ülikool (käsikiri).

Rätsep, H. 1985. Läänemeresoome värvimaailm. Keel ja Kirjandus, nr. 1, 58-59.

Saareste, A. 1958, 1959, 1962, 1963, 1979. Eesti keele mõisteline sõnaraamat I-IV. Huddinge,

Stockholm.

Sahlins, M. 1976. Colors and cultures. Semiotica, Vol. 16, 1, 1-22.

Sapir, E. 1921. Language. New York: Harcourt, Brace \& World.

Sarv, M.; Sarv, T. 1979. Loomise lugu. Eesti Loodus, 7, 449-453. 
Sarv, M.; Sarv, T. 1980. Hanede kadumise lugu. Eesti Loodus, 10, 661-664.

SKES = Suomen kielen etymologinen sanakirja I-VII. 3. tr. Helsinki, 1975-1983.

SKVR = Suomen kansan vanhat runot I-XIV. Helsinki, 1908-1948.

$\mathrm{SL}=$ Setukeste laulud. Pihkva-Eestlaste vanad rahvalaulud, ühes Räpina ja Vastseliina lauludega (I). Toim. J. Hurt. SKS Toimituksia 104. Helsinki, 1904.

Tulviste, P. 1981. Mõtlemise keelelisest ja tegevuslikust relatiivsusest. Keel ja Kirjandus, nr. 6, 329-336.

Turton, D. 1980. There's no such beast: cattle and color naming among the Mursi. Man, Vol. 15, 2, 320-338.

Valentine, C. W. 1962. The Experimental Psychology of Beauty. London: Methuen.

Vals, H. 1962. Pakilist ja praktilist. Edasi, 2. nov.

Vanem Edda. Tlk. R. Sepp. Tallinn, 1970.

Viires, A. 1983. Eestlaste värvimaailm. Keel ja Kirjandus, nr. 6, 291-302.

Vilberg, K. 1939. Leinavärvid. Etnograafia seminaritöö, Tartu Ülikool (käsikiri Eesti Rahva

Muuseumis).

VK VI = Laugaste, E. 1989. Vana kannel VI:2. Haljala regilaulud. Tallinn.

Värvid, arvud, kujundid. Väitlus esivanemate maailmapildist 1981. Looming, nr. 11, 1600-08.

Whorf, B. L. 1956. Language, Thought and Reality. Ed. John B. Carroll. New York: Wiley.

Wiedemann, F. J. (1893) 1973. Ehstnisch-deutsches Wörterbuch. Eesti-saksa sõnaraamat. Neljas, muutmata trükk teisest, Jakob Hurda redigeeritud väljaandest. Tallinn.

Witkowski, S.; Brown, C. H. 1977. An explanation of color nomenclature universals. American Anthropologist, Vol. 79, 50-7.

Õim, A. 1983. Värvinimetuste moodustamisest eesi ja vene keeles. Keel ja Kirjandus, nr. 1, 26-32.

Õim, H. 1974. Semantika. Tallinn. 